\title{
The Value of Epicardial Adipose Tissue for the Patients Treated with Percutaneous Coronary Intervention: A Systemic Review and Meta-analysis
}

\author{
Tan Xu \\ Peking University Third Hospital https://orcid.org/0000-0002-5179-7019 \\ Ming Xu ( $\nabla$ xuminghi@bjmu.edu.cn) \\ Peking University Third Hospital https://orcid.org/0000-0003-1680-3628
}

Research article

Keywords: epicardial adipose tissue, in-stent restenosis, infarct siz, no-reflow, main adverse cardiovascular events, percutaneous coronary intervention

Posted Date: October 12th, 2020

DOI: https://doi.org/10.21203/rs.3.rs-80640/v1

License: @ (i) This work is licensed under a Creative Commons Attribution 4.0 International License. Read Full License 


\section{Abstract}

Background

Accumulating evidences suggest that the prognostic value of epicardial adipose tissue (EAT) on no-reflow, in-stent restenosis (ISR), infarct size, and main adverse cardiovascular events (MACE) for the patients treated with percutaneous coronary intervention (PCI). The relationship between EAT and outcomes of patients underwent $\mathrm{PCl}$ is still partly elusive.

\section{Methods}

To elucidate the relationship in detail, we searched PubMed, web of science, and the Cochrane Library for studies evaluating the association of EAT and patients treated with $\mathrm{PCl}$. Thirteen studies enrolling 3683 patients were eventually include in our systemic review and meta-analysis.

\section{Results}

The EAT measured by thickness or volume was significantly higher in the ISR group compared to those in the non-ISR group (The standard mean difference $-0.34,95 \% \mathrm{Cl},-0.49,-0.18, p<0.0001 ; 1^{2}=36 \%$ ). The incidence of no-reflow was significantly higher in thicker EAT group compared to thin EAT group (pooled relative ratio $1.52,95 \% \mathrm{Cl} 1.29-1,80, p<0.0001 ; \mathrm{I}^{2}=0 \%$ ). Thicker EAT was significantly associated with MACEs (pooled relative ratio $1.50,95 \% 1.18-1.90, p$ $=0.008$ ). A lower EAT volume is associated with larger infarct size in ST elevated myocardial infarction patients treated with primary PCl (standard mean difference was $\left.-5.45,95 \% \mathrm{Cl}-8.10,-2.80 ; p<0.0001 ; 1^{2}=0 \%\right)$. In summary, our systemic review and meta-analysis suggest that high EAT is related with a significant increased risk of non-reflow, MACE and decreased infarct size in patients with coronary artery disease treated with PCI. This paradox phenomenon demonstrates that the quality of EAT may play more important role than the solely thickness or volume of EAT.

\section{Background}

Percutaneous coronary intervention (PCI) is one of the major revascularization strategy for coronary artery disease (CAD), especially the ST segment elevated myocardial infarction (STEMI) [1]. PCI can effectively optimize coronary reperfusion and alleviate ischemic pains, then significantly reduce the mortality and improve the quality of patients' life[2]. However, some complications continually perplex the management of PCl, such as the no-reflow, infarct size reduction, in-stent restenosis (ISR) and main adverse cardiovascular events (MACE)[3].

Accumulating evidences suggest that the prognostic value of epicardial adipose tissue (EAT) on no-reflow, ISR, infarct size and MACE for the patients treated with PCI[4, 5]. previous meta-analysis has been demonstrated that elevated location-specific EAT thickness at the left atrioventricular groove is associated with obstructive coronary artery disease[6]. EAT, directly deposited around the myocardium and epicardial segments of the coronary arteries, has key roles in the adjustment of cardiovascular or systemic physiology and pathophysiology[7]. By autocrine and paracrine means, it generates various types of anti-/proinflammatory mediators and free fatty acids[8]. More recently, multiple clinical researches have shown that increased EAT deposition plays a pivotal role in the development and progression of ISR[9-14], no-reflow[15-18], infarct size[19, 20] or MACE[4, 5, 13, 14] for patients treated with PCI with inconsistent results.

The relationship between EAT and ischemic heart disease might be complex biphasic[21, 22]. Some studies have demonstrated that relationship between larger EAT volume, increased release of inflammatory molecules, and more advanced stages of coronary heart disease[4, 5, 13, 14]. However, patients with cardiomyopathy with left ventricular ejection fraction $<35 \%$ had apparently smaller EAT volume in comparison with healthy controls[22, 23]. Therefore, there exists a paradox between EAT and cardiovascular outcomes in different conditions.

Despite many published articles on the relationship between EAT and outcomes of patients underwent PCl, to the best of our knowledge, the relationship is still partly elusive. Therefore, the present systemic review and meta-analysis was conducted to bridge knowledge gap with the aim of gathering evidences evaluating the prognostic value of EAT for patients underwent PCI. We first briefly overview the relationship of EAT with ISR, and no-reflow. We then move to present key published researches evaluating MACE related with EAT for patients treated with $\mathrm{PCl}$, and discuss remaining challenges.

\section{Methods}

\subsection{Search strategy and selection criteria}

We did this systematic review and meta-analysis in accordance with the Preferred Reporting Items for Systematic Reviews and Meta-Analysis (PRISMA) statement[24].

We searched scientific literature databases for human studies evaluating the value of EAT for patients treated with PCI. We did a systematic search of PubMed, web of science, and the Cochrane Library, using various combinations of keywords such as "epicardial adipose tissue", "epicardial fat", "percutaneous coronary intervention", "Coronary Angioplasty" and "coronary intervention" for eligible studies published up to September 16, 2020. Studies written in English were considered for inclusion; no other languages were allowed.

After initial screening of title and abstracts of the potentially relevant studies, full-texts review of those studies considered relevant were evaluated for eligibility. Criteria for including researches into the systemic review were as follows: (1) studies that involved patients who underwent PCI for any indication (primary PCl, selective PCl, etc.), and (2) studies that reported the association between EAT and outcomes specific to PCI management or MACE. Studies not mentioned the revascularization of $\mathrm{PCl}$ were totally excluded. We also searched conference abstracts that reported data relevant to our research question. On the other hand, case reports were excluded. Two reviewers (TX and MX) independently estimated studies for eligibility.

Page 2/12 


\subsection{Data extraction}

Two reviewers (TX and MX) independently extracted data from the included full-text studies and entered the data into electronic datasheets. They then extracted information about last name of first author, publication year, study design, sample size, demographics, the methods of EAT measurements, the level of EAT and clinical outcomes. Any discrepancies were resolved by consensus with the two aforementioned reviewers, if necessary, after contact with related authors.

\subsection{Outcomes and definitions}

In this systemic review and meta-analysis, the outcomes included ISR, no-reflow, infracted size and MACE. There existed subtle heterogeneity of clinical outcomes and events in categories, such as ISR, no-reflow and MACE. Then we listed all the information related the definition in detail. Additionally, the quantification of EAT and measurement methods exists some distinct difference, such as echocardiographic EAT thickness, or EAT volume measured by computed tomography (CT) or cardiac magnetic resonance(cMR). Therefore, all the aforementioned heterogeneities may attenuate the meta-analysis's efficacy. Therefore, we report the detail of every included study to the greatest extent.

\subsection{Statistical analysis}

Abstracted data from included studies were entered into RevMan 5.3 statistical software (Cochrane Collaboration, Oxford, UK). All the potentially cites of the systemic review and meta-analysis were sorted by the EndNote software. The $\mathrm{I}^{2}$ statistic was used to test heterogeneity, and the studies were pooled using fixed effects models with low heterogeneity $\left(I^{2}<50 \%\right)$. Otherwise, a random-effects model was used.[25] Risk ratio (RR) was used to pool outcomes with a twosided significance level of $5 \%$. Moreover, we also summarized the data as the standard mean difference (SMD) of continuous variables with $95 \%$ Cls when the eligible studies presented related information. Individual trial and summary results are reported with $95 \%$ confidence intervals (Cl). We assessed the quality of the studies using the Newcastle-Ottawa Scale (NOS).[26] Sensitivity analysis was conducted to determine if an individual study was responsible for the observed effect by omitting one study and the risk of publication bias was assessed by examining the funnel plots. Statistical test was two-tailed with $p<$ 0.05 chosen at the level of significance.

\section{Results}

Systemic review of the database retrieved 248 citations. Lots of papers were excluded based on titles and/or abstract due to clearly not relevant. Then 19 potentially appropriate papers included for full text review. According to the inclusion criteria, 13 studies enrolling 3683 patients were eventually include in the systemic review and meta-analysis. One close related study was presented by oral abstract[15]. Systematic review flow chart is depicted in Figure 1. Interestingly, one paper simultaneously evaluated the relationship of ISR and MACE with EAT for patients underwent PCI[13]. Other two studies recruiting the same patients cohort evaluated the influence of EAT on no-reflow, ISR and MACE, respectively[14, 18]. The other 4 studies solely showed the relationship between EAT and ISR of patients treated with PCI[9-12]. The impact of EAT on MACEs for patients treated PCI was evaluated in other 2 studies[4, 5]. Two studies lonely measured the influence of EAT on no-reflow of patients with STEMI treated with primary PCI[15, 17]. Two studies had demonstrated the relationship between EAT measured by CMR and infarct size for STEMI patients treated with primary PCI[19, 20].

\subsection{Description of included studies and quality assessment}

The baselines of included studies' characteristics are summarized in Table 1a, 1b, 1c and $1 \mathrm{~d}$. Average age across all studies 58 years, $77 \%$ of patients were male. According to the included criteria, the patients of all the included studies were treated with PCl for revascularization. Seven studies totally involved 1677 STEMI/non-STEMI patients explicitly mentioned that the revascularization strategy was primary PCI[9, 13-15, 18-20].

Study quality, shown in table 2, was relatively high. Based on the NOS quality assessment, 4 studies were defined as high quality (2 study scored 8 and 5 studies scored 7), and the other 6 studies were defined as moderate quality (4 studies scored 6 and two studies scored 5). 
Table 1a

Study and participant summary characteristic on in-stent restenosis.

\begin{tabular}{|c|c|c|c|c|c|c|c|c|c|}
\hline $\begin{array}{l}\text { Trials } \\
\text { on ISR }\end{array}$ & Study design & Population & $\begin{array}{l}\text { number } \\
\text { of } \\
\text { patients }\end{array}$ & $\begin{array}{l}\text { Mean age } \\
\text { (years) }\end{array}$ & $\begin{array}{l}\text { Male } \\
(\%)\end{array}$ & $\begin{array}{l}\text { EAT } \\
\text { measurement } \\
\text { methods }\end{array}$ & Definition of ISR & $\begin{array}{l}\text { EAT } \\
\text { thickness(mm)/volume } \\
\text { (ml)(ISR VS non-ISR) }\end{array}$ & $\begin{array}{l}\text { Median/me } \\
\text { follow-up }\end{array}$ \\
\hline $\begin{array}{l}\text { Cabrera- } \\
\text { Rego } \\
2019^{8}\end{array}$ & Prospective & STEMI & 169 & $62.9 \pm 10$ & 67.3 & $\begin{array}{l}\text { Echocardiograhy/ } \\
\text { EAT thickness }\end{array}$ & $\begin{array}{l}\geq 50 \% \text { luminal } \\
\text { diameter } \\
\text { narrowing }\end{array}$ & $\begin{array}{l}5.51 \pm 1.6 \text { VS } 4.14 \pm \\
2.0(\mathrm{P}=0.06)\end{array}$ & 1 year \\
\hline $\begin{array}{l}\text { ZHOU } \\
2016^{9}\end{array}$ & Retrospective & CAD & 364 & $61.1 \pm 12.1$ & 90.9 & CT/ EAT volume & $\begin{array}{l}\geq 50 \% \text { luminal } \\
\text { diameter } \\
\text { narrowing }\end{array}$ & $\begin{array}{l}154.5 \pm 74.6 \text { VS } 131.0 \\
\pm 52.2(P=0.008)\end{array}$ & 12.7 month \\
\hline $\begin{array}{l}\text { Park } \\
2013^{10}\end{array}$ & Prospective & CAD & 407 & $59 \pm 11$ & 72.8 & $\begin{array}{l}\text { Echocardiograhy/ } \\
\text { EAT thickness }\end{array}$ & $\begin{array}{l}\text { target lesion } \\
\text { revascularization }\end{array}$ & $\begin{array}{l}3.8 \pm 1.8 \mathrm{VS} 3.2 \pm 1.9 \\
(\mathrm{P}=0.002)\end{array}$ & 12 months \\
\hline $\begin{array}{l}\text { Nikaeen } \\
2011^{11}\end{array}$ & Retrospective & CAD & 117 & $57.6 \pm 9.6$ & 60.7 & $\begin{array}{l}\text { Echocardiograhy/ } \\
\text { EAT thickness }\end{array}$ & $\begin{array}{l}\geq 50 \% \text { luminal } \\
\text { diameter } \\
\text { narrowing }\end{array}$ & $\begin{array}{l}4.4 \pm 1.8 \mathrm{VS} 4.52 \pm 1.9 \\
(P=0.8)\end{array}$ & 1 year \\
\hline $\begin{array}{l}\text { Park } \\
2016^{12}\end{array}$ & Prospective & STEMI & 761 & $57 \pm 12$ & 80.7 & $\begin{array}{l}\text { Echocardiograhy/ } \\
\text { EAT thickness }\end{array}$ & $\begin{array}{l}\text { Target lesion } \\
\text { revascularization }\end{array}$ & / & 46 months \\
\hline $\begin{array}{l}\text { Zencirci } \\
2015^{13}\end{array}$ & Prospective & STEMI & 114 & $54 \pm 10$ & 86.8 & $\begin{array}{l}\text { Echocardiograhy/ } \\
\text { EAT thickness }\end{array}$ & $\begin{array}{l}\text { Target-vessel } \\
\text { revascularisation }\end{array}$ & / & 3 year \\
\hline
\end{tabular}

ISR, in-stent restenosis; EAT, epicardial adipocyte tissue; STEMI, ST segment elevated myocardial infarction; CAD, coronary artery disease.

Table 1b

Study and participant summary characteristic on no-reflow.

\begin{tabular}{|c|c|c|c|c|c|c|c|c|}
\hline $\begin{array}{l}\text { Trials on } \\
\text { no-reflow }\end{array}$ & $\begin{array}{l}\text { Study } \\
\text { design }\end{array}$ & Population & $\begin{array}{l}\text { number } \\
\text { of } \\
\text { patients }\end{array}$ & $\begin{array}{l}\text { Mean } \\
\text { age } \\
\text { (years) }\end{array}$ & $\begin{array}{l}\text { Male } \\
(\%)\end{array}$ & $\begin{array}{l}\text { EAT measurement } \\
\text { methods }\end{array}$ & $\begin{array}{l}\text { EAT } \\
\text { thickness(mm) } \\
\text { No-flow VS } \\
\text { normal }\end{array}$ & Definition of no-reflow \\
\hline Cerit. $2018^{14}$ & retrospective & STEMI & 249 & / & / & $\begin{array}{l}\text { Echocardiogram/EAT } \\
\text { thickness }\end{array}$ & I & / \\
\hline $\begin{array}{l}\text { Bakirci } \\
2015^{16}\end{array}$ & Prospective & STEMI & 229 & $\begin{array}{l}54.3 \pm \\
10.1\end{array}$ & 77.7 & $\begin{array}{l}\text { Echocardiogram } \\
\text { /EAT thickness }\end{array}$ & $\begin{array}{l}6.4 \pm 0.9 v s 5.5 \pm 1.3 \\
(p<0.001)\end{array}$ & $\begin{array}{l}\text { Postprocedural TIMI flow } \\
\text { grade }\end{array}$ \\
\hline $\begin{array}{l}\text { Zencirci } \\
2014^{17}\end{array}$ & Prospective & STEMI & 114 & $54 \pm 10$ & 86.8 & $\begin{array}{l}\text { Echocardiogram } \\
\text { /EAT thickness }\end{array}$ & $\begin{array}{l}5.4 \pm 2 \text { VS } 3.9 \pm \\
1.7 \\
P=0.001\end{array}$ & $\begin{array}{l}\text { Patients with } \triangle S T R<70 \% \\
\text { were accepted as no-reflow } \\
\text { phenomenon group }\end{array}$ \\
\hline $\begin{array}{l}\text { EAT, epicardi } \\
\text { resolution of } \\
\text { second ECG }\end{array}$ & dipocyte tiss & $\begin{array}{l}\text { STEMI, ST S } \\
\text { nent elevatic }\end{array}$ & $\begin{array}{l}\text { gment el } \\
\text { and exp }\end{array}$ & $\begin{array}{l}\text { ted myoc } \\
\text { sed as } \triangle\end{array}$ & $\begin{array}{l}\text { dial inf } \\
\text { R (Mea }\end{array}$ & $\begin{array}{l}\text { ction; } \triangle S T R \text {, the differ } \\
\text { urements were obtaine }\end{array}$ & $\begin{array}{l}\text { ce between two me } \\
\text { rom the first ECG, } r\end{array}$ & $\begin{array}{l}\text { surements was accepted as } \\
\text { corded on admission and a }\end{array}$ \\
\hline
\end{tabular}

Table 1c

Study and participant summary characteristic on main adverse cardiovascular events.

\begin{tabular}{|c|c|c|c|c|c|c|c|c|}
\hline $\begin{array}{l}\text { Trials on } \\
\text { MACEs }\end{array}$ & $\begin{array}{l}\text { Study } \\
\text { design }\end{array}$ & Population & $\begin{array}{l}\text { number } \\
\text { of } \\
\text { patients }\end{array}$ & $\begin{array}{l}\text { Mean age } \\
\text { (years) }\end{array}$ & $\begin{array}{l}\text { Male } \\
(\%)\end{array}$ & $\begin{array}{l}\text { EAT measurement } \\
\text { methods }\end{array}$ & Definition of MACEs & $\begin{array}{l}\text { Median } \\
\text { follow- } \\
\text { up }\end{array}$ \\
\hline $\begin{array}{l}\text { Lu } \\
2019^{4}\end{array}$ & Prospective & CAD & 500 & 58.9 & 59.2 & CT/EAT volume & $\begin{array}{l}\text { death, myocardial infarction, and } \\
\text { revascularization }\end{array}$ & $\begin{array}{l}25.2 \\
\text { months }\end{array}$ \\
\hline $\begin{array}{l}\text { Tscharre } \\
2017^{5}\end{array}$ & Prospective & ACS & 438 & $62.6 \pm 13.5$ & 66.9 & $\begin{array}{l}\text { Echocardiogram/EAT } \\
\text { thickness }\end{array}$ & $\begin{array}{l}\text { cardiovascular death, non-fatal myocardial } \\
\text { infarction and non-fatal stroke }\end{array}$ & 3 years \\
\hline $\begin{array}{l}\text { Park } \\
2016^{12}\end{array}$ & Prospective & STEMI & 761 & $57 \pm 12$ & 80.7 & $\begin{array}{l}\text { Echocardiogram/EAT } \\
\text { thickness }\end{array}$ & $\begin{array}{l}\text { all-cause death, recurrent myocardial } \\
\text { infarction and target vessel } \\
\text { revascularisation. }\end{array}$ & $\begin{array}{l}46 \\
\text { months }\end{array}$ \\
\hline $\begin{array}{l}\text { Zencirci } \\
2015^{13}\end{array}$ & Prospective & STEMI & 114 & $54 \pm 10$ & 86.8 & $\begin{array}{l}\text { Echocardiogram/EAT } \\
\text { thickness }\end{array}$ & $\begin{array}{l}\text { cardiac death, non-fatal myocardial } \\
\text { infarction, target vessel revascularisation, } \\
\text { or admission for heart failure }\end{array}$ & 3 years \\
\hline
\end{tabular}


Table 1d

Study and participant summary characteristic on related with infarct size.

\begin{tabular}{|c|c|c|c|c|c|c|c|}
\hline $\begin{array}{l}\text { Trials on infarct } \\
\text { size }\end{array}$ & $\begin{array}{l}\text { Study } \\
\text { design }\end{array}$ & Population & $\begin{array}{l}\text { number of } \\
\text { patients }\end{array}$ & $\begin{array}{l}\text { Mean age } \\
\text { (years) }\end{array}$ & $\begin{array}{l}\text { Male } \\
(\%)\end{array}$ & $\begin{array}{l}\text { EAT measurement } \\
\text { methods }\end{array}$ & $\begin{array}{l}\text { Infarct size (\% LV mass) } \\
\text { (EAT low vs high) }\end{array}$ \\
\hline Gohbara $2016^{18}$ & Prospective & STEMI & 142 & $64 \pm 12$ & 85.0 & CMR/EAT volume & $25 \pm 10$ vs $19 \pm 10^{a} p<0.01$ \\
\hline Bière $2017^{19}$ & Prospective & STEMI & 193 & $58 \pm 12$ & 85.5 & CMR/EAT volume & $\begin{array}{l}23 \pm 13.7 \text { VS } 18.3 \pm 11.9^{b} \\
p=0.041\end{array}$ \\
\hline \multicolumn{8}{|c|}{$\begin{array}{l}\text { EAT, epicardial adipocyte tissue; STEMI, ST segment elevated myocardial infarction; } \\
\text { a.low and high group Patients belonging to the lower tertile of EAT volume were categorized into the low EAT group (group L) and the other two-thirds intc } \\
\text { the high EAT group (group H); b. quartile } 1^{\text {st }} \text { VS quartile } 4^{\text {th }}\end{array}$} \\
\hline
\end{tabular}

Table 2

Assessment of study quality.

\begin{tabular}{|c|c|c|c|c|c|c|c|c|c|}
\hline \multirow[t]{2}{*}{ Reference } & \multicolumn{8}{|c|}{ Quality Indications of Newcastle-Ottawa Scale Total } & \multirow[t]{2}{*}{ Total } \\
\hline & 1 & 2 & 3 & 4 & 5 & 6 & 7 & 8 & \\
\hline Cabrera-Rego $2019^{8}$ & Yes & Yes & Yes & Yes & Yes & Yes & Yes & Yes & 8 \\
\hline ZHOU $2016^{9}$ & Yes & Yes & Yes & Yes & Yes & Yes & No & Yes & 7 \\
\hline Park $2013^{10}$ & Yes & Yes & Yes & Yes & Yes & Yes & Yes & No & 7 \\
\hline Nikaeen $2011^{11}$ & Yes & Yes & Yes & Yes & No & Yes & Yes & Yes & 7 \\
\hline Park $2016^{12}$ & Yes & Yes & No & Yes & No & Yes & Yes & Yes & 6 \\
\hline Zencirci $2015^{13}$ a & No & Yes & Yes & Yes & Yes & Yes & No & No & 5 \\
\hline Cerit.2018 & Yes & Yes & No & Yes & No & No & Yes & Yes & 5 \\
\hline Bakirci $2015^{16}$ & No & Yes & Yes & Yes & Yes & Yes & Yes & No & 6 \\
\hline Zencirci $2014^{17}$ & Yes & No & Yes & Yes & Yes & Yes & Yes & Yes & 7 \\
\hline Lu $2019^{4} a$ & No & Yes & Yes & Yes & Yes & Yes & No & Yes & 6 \\
\hline Tscharre $2017^{5} \mathrm{~b}$ & Yes & Yes & Yes & Yes & Yes & Yes & Yes & Yes & 8 \\
\hline Gohbara $2016^{18}$ & Yes & Yes & Yes & No & Yes & Yes & Yes & Yes & 7 \\
\hline Bière $2017^{19}$ & Yes & Yes & No & Yes & Yes & No & Yes & Yes & 6 \\
\hline
\end{tabular}

\subsection{Quantitative data synthesis}

\section{The value of EAT for ISR}

There are totally 6 studies evaluated the value of EAT for the ISR[9-14]. The EAT measured by thickness or volume was significantly higher in the ISR group compared to those in the non-ISR group. The standard mean difference was -0.34 estimated in 4 studies[9-12] $\left(95 \% \mathrm{Cl},-0.49,-0.18 \rrbracket p<0.0001 ; I^{2}=36 \%\right)(\mathrm{Fig} .2 \mathrm{a})$. However, the value of EAT was not associated with the incidence of ISR when evaluated in five include studies[9-11, 13, 14] ( pooled RR 1.23, 95\%Cl 0.97-1.56, $p=0.09 ; I^{2}=82 \%$ ) (Fig. 2b). The discrepancy may partly due to the distinct heterogeneity of included studies and the different definition of ISR.

\section{The value of EAT on no-reflow}

The incidence of no-reflow was significantly higher in thicker EAT group compared to thin EAT group (pooled RR 1.52, 95\%Cl 1.29-1.80, $p<0.0001 ; I^{2}=0 \%$ ) (Fig.3a). In the meanwhile, the EAT thickness was higher in the non-reflow group than those in the normal reflow group (SMD $-0.94,95 \% \mathrm{Cl},-1.41,-0.47, p<0.001$; $\mathrm{I}^{2}=64 \%$ ) (Fig. 3b). 


\section{The prognostic value of EAT on MACEs}

There were totally 4 studies[4,5] included 1813 CAD patients showed thicker EAT was significantly associated with MACE (pooled RR 1.50, 95\% 1.18-1.90, $p=0.008$ ) (Fig4). Although these data were not statistically heterogeneous $\left(I^{2}=0 \%\right)$, yet the definition varied between included studies.

\section{Relationship between EAT and infarct size}

Two eligible studies $[19,20]$ included 335 STEMI patients treated with primary PCI reported the relationship between EAT volume and infarct size, which are both measured by cMR. There was no heterogeneous $\left(I^{2}=0 \%\right)$ between the two studies. The SMD was $-5.45(95 \% \mathrm{Cl}-8.10,-2.80 ; \mathrm{p}<0.0001)(\mathrm{Fig} 5)$. This suggested that a lower EAT volume is associated with larger infarct size in STEMI patients treated with primary PCI.

\subsection{Heterogeneity among Included Studies}

Five included studies, evaluated the relation between EAT and ISR, exist evident heterogeneous which may partly due to the difference definition of ISR. The other main studies have minor or no heterogeneity shown in the aforementioned forest plot. Unfortunately, due to the small number of included studies, we could not explore the detail sources of heterogeneity with subgroup analysis or meta-regression.

\subsection{Publication Bias and Funnel Plots}

The statistical assessment of publication bias was not found in the main comparison outcomes. The funnel plots showed each comparison outcomes in detail (Supplement S1a, S1b, S1c and S1d).

\subsection{Sensitivity analyses}

To analyze sensitivity, the primary results were not influenced by omitting one study. However, comparison between EAT and infarct size only contains two studies, so the sensitivity analysis can't perform. (Supplement S2a, S2b, S3 and S4)

\section{Discussion}

In this systemic review and meta-analysis including 13 studies in the era of PCl, we demonstrated high EAT is associated with a statistically significant increased risk of non-reflow, MACEs and decreased infarct size in patients with CAD. However, EAT was not clearly associated with ISR.

EAT was shown to be more than a simple adipose tissue depot, since it is recognized as an extraordinarily active endocrine organ. Then it may have either a beneficial or detrimental effect depending on the homeostasis[27]. Accumulated evidences suggest that EAT secretes anti/pro-inflammatory hormones and cytokines which play dual pro-atherogenic and anti-atherogenic roles in the pathogenesis of coronary atherosclerosis[28]. EAT was also recognized as a metabolic transducer role in coronary artery disease[29]. More and more studies shown EAT plays a pivotal role in the outcomes of CAD patients in the era of $\mathrm{PCl}$, such as the infarct size, non-reflow and ISR. In this meta-analysis thicker EAT was related with some detrimental effects, for example non-reflow and MACEs.

Inflammation mediated by neutrophil activation was shown to have an undeniable role in the pathogenesis of no-reflow phenomenon[30]. Takaoka et al found that endovascular injury induces rapid and marked changes in perivascular adipose tissue, mainly mediated by TNF-a[31]. EAT may secret more proinflammatory factors to induce the no-reflow. In this meta-analysis, the effect pooled from 3 studies included STEMI patients treated with primary PCI demonstrated that the incidence of no-reflow was significantly higher in thicker EAT group, possibly due to EAT's pro-inflammatory role activated by coronary injury.

The mechanisms of ISR are complex, due to its affected by multi-factor[32]. The factors may involve clinical (senior, sex ,diabetes mellitus, dyslipidemia, obesity and smoking), angiographic factors (proximal lesions, $\mathrm{PCl}$ on the main left coronary artery, arteries of small diameter, long stenosis, use of bare metal stents) and factors inherent to the procedure (neointimal hyperplasia, mural thrombus)[32]. Many studies demonstrated that higher EAT was significantly associated with ISR[9-14]. Interestingly, this meta-analysis shown that the association between EAT and ISR may not clear, although the ISR groups had higher EAT. This may partly due to the complex of ISR and the bidirectional relationship between EAT and CAD[22]. Further studies are needed to elucidate the relationship between EAT and ISR.

Despite the different definition of MACEs in this meta-analysis, the pooled results also demonstrated that higher EAT was associated with worse outcomes. In the meanwhile, this results may be confirmed by recent study aimed at investigating the effect of statins on EAT[33]. EAT is a new target for statin therapy, and statin's effect on EAT size and phenotype may be strongly involved in beneficial cardiovascular outcomes in statin-treated patients[34].

Epicardial adipose tissue volume is not a simple marker of coronary artery disease[35]. Although the thicker or higher volume EAT may have detrimental effect on cardiovascular outcomes as the aforementioned results, yet it is interesting to note that high EAT was paradoxically associated with less infarct size and acted as an effect modifier in the relation between the extent of infarct size[36]. The results were in accordance with the other study[37]. Correspondingly, the meta-analysis also demonstrated that a lower EAT volume is associated with larger infarct size. This suggests that EAT may have a cardioprotective effect in 
a specific condition, such as acute myocardial infarction. Potential benefits might be associated with local hormonal release of adiponectin, or to the fact that EAT may be serving as an energy reservoir in the condition of acute myocardial infarct[38].

Coincidentally, obese patients also have thicker EAT. Recently large meta-analyses of patients with acute myocardial infarction have shown that patients in the overweight and obese groups have lower short-term and long-term all-cause mortality compared with patients in the normal weight group[39, 40]. Franssens et al's finding supported that EAT radiodensity may be a more sensitive marker than EAT volume. Some studies have shown that higher expression levels of uncoupling protein 1, a brown adipose tissue specific protein, in EAT compared to other adipose tissue depots[41]. This may suggest human EAT exists brown adipocytes or brite/beige cells at adult stage[7]. It is likely that increasing the brite/beige cells in white adipose tissue might also have greater metabolic benefits[42]. This urges us to determine the quality of EAT rather than the solely thickness or volume of EAT. Recently, Yu Du and his colleagues have shown that lesion-specific EAT volume index, but not density, seems positively and independently associated with myocardial ischemia[43]. In some way, quantification of epicardial fat using 3D cine Dixon MRI may play a pivotal role in determining the quality of EAT[44].

The present study must be interpreted within the context of its potential limitations. Firstly, the number of included studies is relatively small. Secondly, heterogeneity: There was significant heterogeneity among EAT and ISR or reflow. However, as a result of the limited number of included studies for each outcome, we couldn't precisely identify the sources of heterogeneity. Thirdly, the included studies have not the same criteria for ISR and MACEs, which may have substantial detrimental on the explanation of the pooled results. Fourthly, the included studies are mainly prospective study, partially hindering the explanation of the causation and effect between EAT and relative events.

\section{Conclusions}

Our systemic review and meta-analysis suggest that high EAT is related with a significant increased risk of non-reflow, MACEs and decreased infarct size in patients with CAD treated with $\mathrm{PCl}$. This paradox phenomenon demonstrates that the quality of EAT may play more important role than the solely thickness or volume of EAT.

\section{Abbreviations}

EAT, epicardial adipose tissue;

ISR, in-stent restenosis;

MACE, main adverse cardiovascular events;

$\mathrm{PCl}$, percutaneous coronary intervention;

CAD, coronary artery disease;

STEMI, segment elevated myocardial infarction;

PRISMA, Preferred Reporting Items for Systematic Reviews and Meta-Analysis;

Cl, confidence intervals;

SMD, standard mean difference;

CT, computed tomography;

cMR, cardiac magnetic resonance;

NOS, Newcastle-Ottawa Scale;

SMD, standard mean difference;

RR, Risk ratio;

\section{Declarations}

\section{Ethics approval and consent to participate Consent for publication Availability of data and material}

All the included studies have appropriate ethics approval and consent. All the data and material will be available by contacting the corresponding author. All authors approved the manuscript for submission to the journal.

\section{Competing interests}

The authors declare that they have no competing interests. 


\section{Funding}

This work was partially supported by the National Natural Science Foundation of China $(81625001,91854209,31630035)$ and the National Key Research \& Development Program of China (2018YFC1312700, 2018YFC1312701). The recipient of all the funds is Ming Xu.

\section{Authors' contributions}

Conceived and designed the systemic review and meta-analysis: TX and MX. Analyzed the data: TX. Wrote the paper: TX and MX. All authors read and approved the final manuscript.

\section{Acknowledgements}

We sincerely thanked Dr. Tong Liu's comments for the improvement of the manuscript.

\section{References}

1. Neumann FJ, Sousa-Uva M, Ahlsson A, Alfonso F, Banning AP, Benedetto U, Byrne RA, Collet JP, Falk V, Head SJ et al: 2018 ESC/EACTS Guidelines on myocardial revascularization. Eur Heart J 2019, 40(2):87-165.

2. Gada H, Kirtane AJ, Kereiakes DJ, Bangalore S, Moses JW, Genereux P, Mehran R, Dangas GD, Leon MB, Stone GW: Meta-analysis of trials on mortality after percutaneous coronary intervention compared with medical therapy in patients with stable coronary heart disease and objective evidence of myocardial ischemia. Am J Cardio/ 2015, 115(9):1194-1199.

3. Kandan SR, Johnson TW: Management of percutaneous coronary intervention complications. Heart 2019, 105(1):75-86.

4. Lu CQ, Jia HL, Wang ZT: Association between epicardial adipose tissue and adverse outcomes in coronary heart disease patients with percutaneous coronary intervention. Bioscience Rep 2019, 39.

5. Tscharre M, Hauser C, Rohla M, Freynhofer MK, Wojta J, Huber K, Weiss TW: Epicardial adipose tissue and cardiovascular outcome in patients with acute coronary syndrome undergoing percutaneous coronary intervention. Eur Heart J-Acute Ca 2017, 6(8):750-752.

6. Wu FZ, Chou KJ, Huang YL, Wu MT: The relation of location-specific epicardial adipose tissue thickness and obstructive coronary artery disease: systemic review and meta-analysis of observational studies. BMC Cardiovasc Disord 2014, 14:62.

7. Patel VB, Shah S, Verma S, Oudit GY: Epicardial adipose tissue as a metabolic transducer: role in heart failure and coronary artery disease. Heart Fail Rev 2017, 22(6):889-902.

8. lacobellis G, Bianco AC: Epicardial adipose tissue: emerging physiological, pathophysiological and clinical features. Trends Endocrinol Metab 2011, 22(11):450-457.

9. Cabrera-Rego JO, Escobar-Torres RA, Parra-Jimenez JD, Valiente-Mustelier J: Epicardial fat thickness correlates with coronary in-stent restenosis in patients with acute myocardial infarction. Clin Invest Arterios 2019, 31(2):49-55.

10. Zhou Y, Zhang HW, Tian F, Chen JS, Han TW, Tan YH, Zhou J, Zhang T, Jing J, Chen YD: Influence of increased epicardial adipose tissue volume on 1-year in-stent restenosis in patients who received coronary stent implantation. J Geriatr Cardiol 2016, 13(9):768-775.

11. Park JS, Choi BJ, Choi SY, Yoon MH, Hwang GS, Tahk SJ, Shin JH: Echocardiographically measured epicardial fat predicts restenosis after coronary stenting. Scandinavian Cardiovascular Journal 2013, 47(5):297-302.

12. Nikaeen F, Pourmoghadas M, Shemirani H, Ahmad Mirdamadi S, Akbari M: The association between epicardial fat thickness in echocardiography and coronary restenosis in drug eluting stents. ARYA Atheroscler 2011, 7(1):11-17.

13. Park JS, Lee YH, Seo KW, Choi BJ, Choi SY, Yoon MH, Hwang GS, Tahk SJ, Shin JH: Echocardiographic epicardial fat thickness is a predictor for target vessel revascularization in patients with ST-elevation myocardial infarction. Lipids Health Dis 2016, 15.

14. Zencirci AE, Zencirci E, Degirmencioglu A, Erdem A, Karakus G, Ozden K, Karadeniz F, Buturak A, Belen E, Tipi F et al: Predictive Value of the No-Reflow Phenomenon and Epicardial Adipose Tissue for Clinical Outcomes After Primary Percutaneous Coronary Intervention. Hellenic J Cardio/ 2015, 56(4):311319.

15. Cerit L: Association between epicardial adipose tissue and coronary no-reflow phenomenon. Gazz Med Ital Arch S2018, 177(7-8):367-373.

16. Sen F, Yilmaz S, Balci KG, Gul M, Balci MM, Akboga MK, Topaloglu S, Temizhan A, Aras D, Aydogdu S: The Relationship Between Epicardial Adipose Tissue Thickness and Infarct-Related Artery Patency in Patients With ST-Segment Elevation Myocardial Infarction. Angiology 2016, 67(3):281-286.

17. Bakirci EM, Degirmenci H, Duman H, Inci S, Hamur H, Buyuklu M, Ceyhun G, Topal E: Increased Epicardial Adipose Tissue Thickness is Associated With Angiographic Thrombus Burden in the Patients With Non-ST-Segment Elevation Myocardial Infarction. Clin App/ Thromb-Hem 2015, 21(7):612-618.

18. Zencirci E, Zencirci AE, Degirmencioglu A, Karakus G, Ugurlucan M, Ozden K, Erdem A, Gullu AU, Ekmekci A, Velibey Y et al: The relationship between epicardial adipose tissue and ST-segment resolution in patients with acute ST-segment elevation myocardial infarction undergoing primary percutaneous coronary intervention. Heart and Vessels 2015, 30(2):147-153.

19. Gohbara M, Iwahashi N, Akiyama E, Maejima N, Tsukahara K, Hibi K, Kosuge M, Ebina T, Umemura S, Kimura K: Association between epicardial adipose tissue volume and myocardial salvage in patients with a first ST-segment elevation myocardial infarction: An epicardial adipose tissue paradox. Journal of Cardiology 2016, 68(5-6):399-405. 
20. Biere L, Behaghel V, Mateus V, Assuncao A, Grani C, Ouerghi K, Grall S, Willoteaux S, Prunier F, Kwong R et al: Relation of Quantity of Subepicardial Adipose Tissue to Infarct Size in Patients With ST-Elevation Myocardial Infarction. American Journal of Cardiology 2017, 119(12):1972-1978.

21. Doesch C, Haghi D, Suselbeck T, Schoenberg SO, Borggrefe M, Papavassiliu T: Impact of Functional, Morphological and Clinical Parameters on Epicardial Adipose Tissue in Patients With Coronary Artery Disease. Circulation Journal 2012, 76(10):2426-2434.

22. Schoenhagen P, Xu M: Complex Biphasic Relationship Between Epicardial Fat and Ischemic Heart Disease. Circulation Journal 2012, 76(10):2333-2334.

23. Doesch C, Haghi D, Fluchter S, Suselbeck T, Schoenberg SO, Michaely H, Borggrefe M, Papavassiliu T: Epicardial adipose tissue in patients with heart failure. J Cardiovasc Magn Reson 2010, 12:40.

24. Liberati A, Altman DG, Tetzlaff J, Mulrow C, Gotzsche PC, loannidis JP, Clarke M, Devereaux PJ, Kleijnen J, Moher D: The PRISMA statement for reporting systematic reviews and meta-analyses of studies that evaluate healthcare interventions: explanation and elaboration. BMJ 2009, 339:b2700.

25. Higgins JP, Thompson SG, Deeks JJ, Altman DG: Measuring inconsistency in meta-analyses. BMJ 2003, 327(7414):557-560.

26. Stang A: Critical evaluation of the Newcastle-Ottawa scale for the assessment of the quality of nonrandomized studies in meta-analyses. Eur $J$ Epidemiol 2010, 25(9):603-605.

27. Gaborit B, Sengenes C, Ancel P, Jacquier A, Dutour A: Role of Epicardial Adipose Tissue in Health and Disease: A Matter of Fat? Compr Physiol 2017, 7(3):1051-1082.

28. Iozzo P: Myocardial, perivascular, and epicardial fat. Diabetes Care 2011, 34 Suppl 2:S371-379.

29. Patel VB, Shah S, Verma S, Oudit GY: Epicardial adipose tissue as a metabolic transducer: role in heart failure and coronary artery disease. Heart Failure Reviews 2017, 22(6):889-902.

30. Celik T, lyisoy A, Yuksel UC, Jata B, Ozkan M: The impact of admission C-reactive protein levels on the development of no-reflow phenomenon after primary PCl in patients with acute myocardial infarction: the role of inflammation. Int J Cardio/ 2009, 136(1):86-88; author reply 88-89.

31. Takaoka M, Suzuki H, Shioda S, Sekikawa K, Saito Y, Nagai R, Sata M: Endovascular injury induces rapid phenotypic changes in perivascular adipose tissue. Arterioscler Thromb Vasc Biol 2010, 30(8):1576-1582.

32. Safian RD: Restenosis after PCl: Battered but not beaten. Catheter Cardiovasc Interv 2016, 87(2):209-210.

33. Parisi V, Petraglia L, D'Esposito V, Cabaro S, Rengo G, Caruso A, Grimaldi MG, Baldascino F, De Bellis A, Vitale D et al: Statin therapy modulates thickness and inflammatory profile of human epicardial adipose tissue. Int J Cardiol 2019, 274:326-330.

34. Beltowski J: Epicardial adipose tissue: The new target for statin therapy. Int J Cardiol 2019, 274:353-354.

35. Yamada H: Epicardial adipose tissue volume is not a simple marker of coronary artery disease. Int J Cardiol 2020.

36. Gohbara M, Iwahashi N, Akiyama E, Maejima N, Tsukahara K, Hibi K, Kosuge M, Ebina T, Umemura S, Kimura K: Association between epicardial adipose tissue volume and myocardial salvage in patients with a first ST-segment elevation myocardial infarction: An epicardial adipose tissue paradox. $J$ Cardiol 2016, 68(5):399-405.

37. Zencirci E, Zencirci AE, Degirmencioglu A, Karakus G, Ugurlucan M, Ozden K, Erdem A, Gullu AU, Ekmekci A, Velibey Y et al: The relationship between epicardial adipose tissue and ST-segment resolution in patients with acute ST-segment elevation myocardial infarction undergoing primary percutaneous coronary intervention. Heart Vessels 2015, 30(2):147-153.

38. lacobellis G, Barbaro G: The double role of epicardial adipose tissue as pro- and anti-inflammatory organ. Horm Metab Res 2008, 40(7):442-445.

39. Niedziela J, Hudzik B, Niedziela N, Gasior M, Gierlotka M, Wasilewski J, Myrda K, Lekston A, Polonski L, Rozentryt P: The obesity paradox in acute coronary syndrome: a meta-analysis. Eur J Epidemio/ 2014, 29(11):801-812.

40. Wang L, Liu W, He X, Chen Y, Lu J, Liu K, Cao K, Yin P: Association of overweight and obesity with patient mortality after acute myocardial infarction: a meta-analysis of prospective studies. Int J Obes (Lond) 2016, 40(2):220-228.

41. Chechi K, Blanchard PG, Mathieu P, Deshaies Y, Richard D: Brown fat like gene expression in the epicardial fat depot correlates with circulating HDLcholesterol and triglycerides in patients with coronary artery disease. Int J Cardiol 2013, 167(5):2264-2270.

42. Srivastava S, Veech RL: Brown and Brite: The Fat Soldiers in the Anti-obesity Fight. Front Physiol 2019, 10:38.

43. Du Y, Yang L, Liu Y, Yang B, Lv S, Hu C, Zhu Y, Zhang H, Ma Q, Wang Z et al: Relation between quantity and quality of peri-coronary epicardial adipose tissue and its underlying hemodynamically significant coronary stenosis. BMC Cardiovasc Disord 2020, 20(1):226.

44. Henningsson M, Brundin M, Scheffel T, Edin C, Viola F, Carlhall CJ: Quantification of epicardial fat using 3D cine Dixon MRI. BMC Med Imaging 2020, 20(1):80.

\section{Figures}




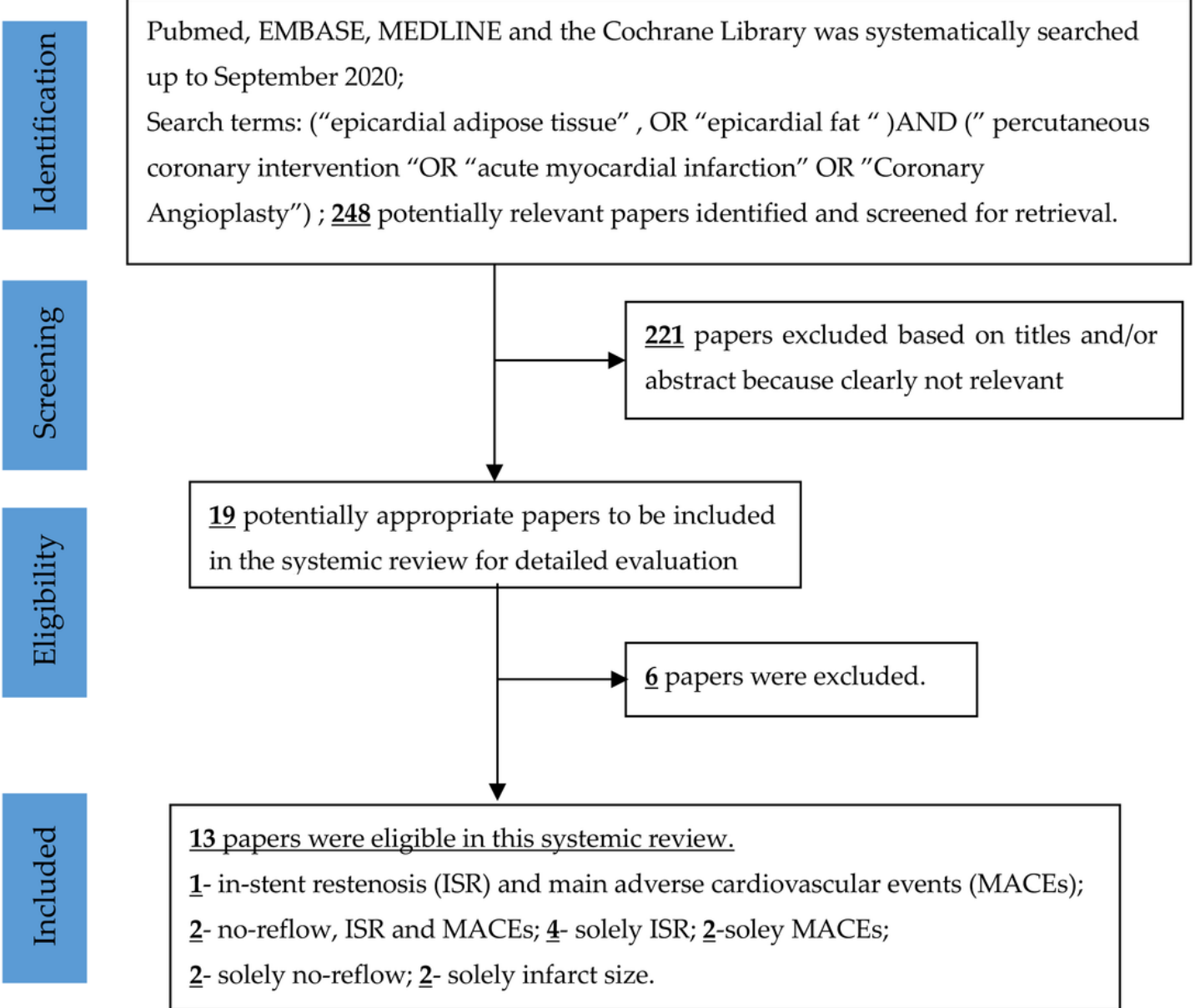

\section{Figure 1}

Flowchart of study selection process to determine the studies to be included in the meta-analysis. 
(A)

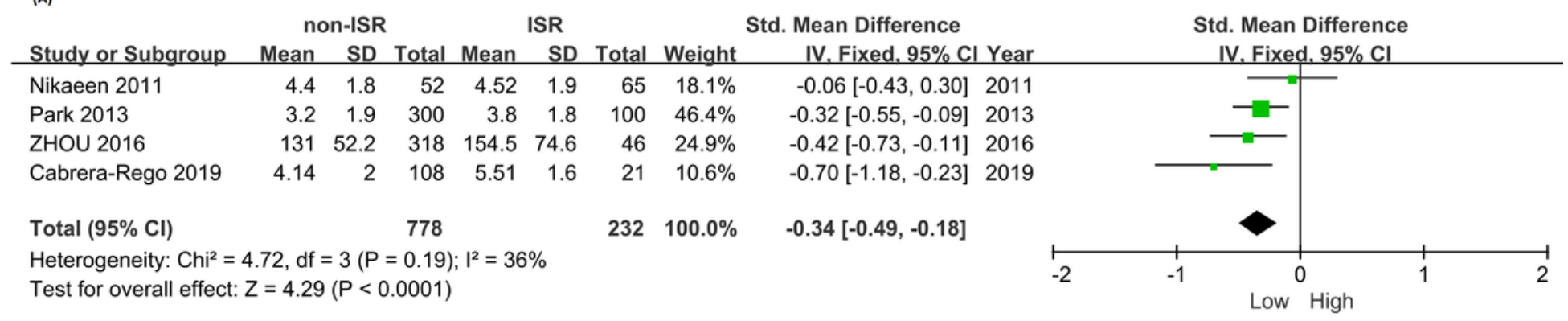

(B)

Study or Subgroup log[Risk Ratio]

Park 2013

Zencirci 2015

ZHOU 2016

Park 2016

Cabrera-Rego 2019

$\begin{array}{rrr}0.17395331 & 0.070211 & 33.2 \% \\ -0.22314 & 0.491824 & 5.2 \% \\ 0.00354 & 0.00896 & 37.3 \% \\ 1.76575767 & 0.47431816 & 5.6 \% \\ 0.3220835 & 0.19743653 & 18.7 \%\end{array}$

$100.0 \%$

Total $(95 \% \mathrm{Cl})$

Risk Ratio

IV. Random, $95 \% \mathrm{Cl}$ Year

Risk Ratio

$1.19[1.04,1.37] 2013$

$0.80[0.31,2.10] 2015$

$1.00[0.99,1.02] 2016$

$5.85[2.31,14.81] 2016$

$1.38[0.94,2.03] 2019$

Heterogeneity: $\mathrm{Tau}^{2}=0.04 ; \mathrm{Chi}^{2}=22.32, \mathrm{df}=4(\mathrm{P}=0.0002) ; \mathrm{I}^{2}=82 \%$

Test for overall effect: $Z=1.70(P=0.09)$

$1.23[0.97,1.56]$

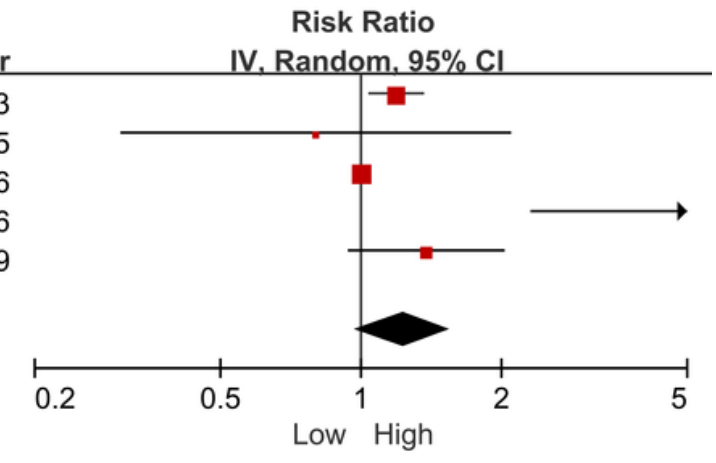

Figure 2

(A) Forest plot evaluated the impact of EAT divided by ISR vs non-ISR. (B) Forest plot evaluated the value of EAT for ISR.

(A)

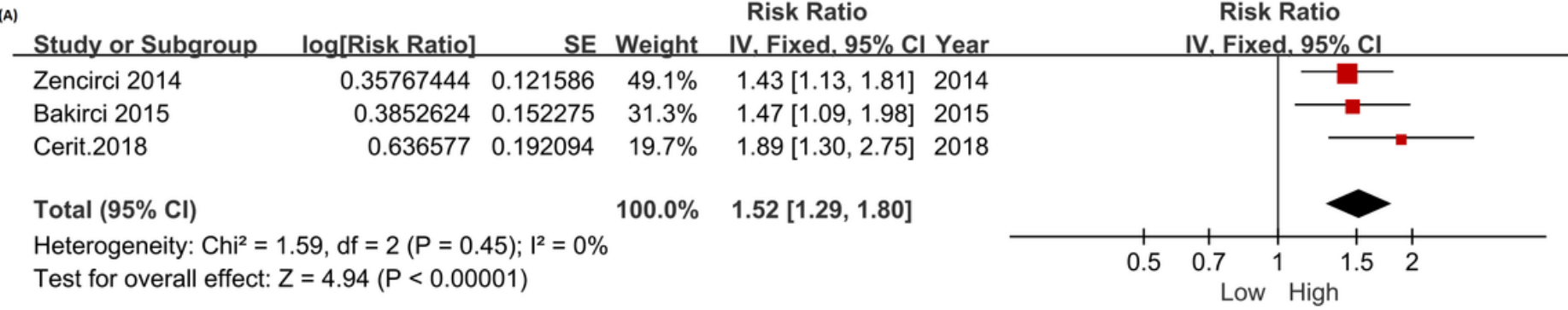

(B)

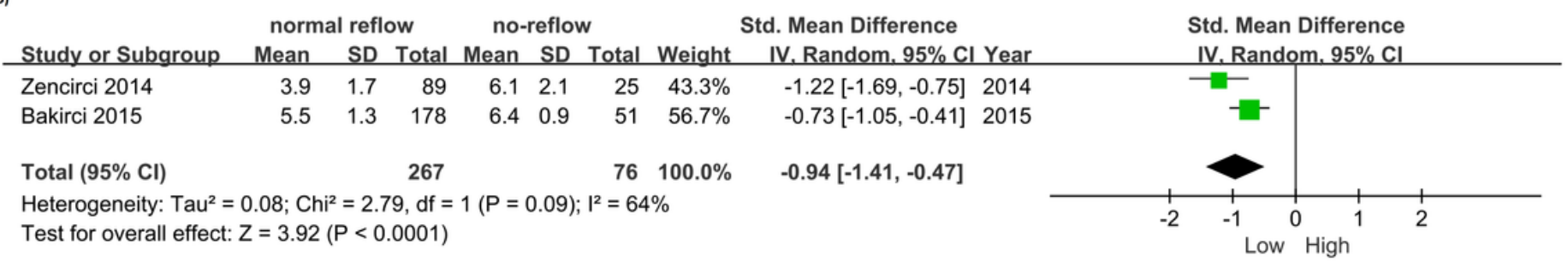

Figure 3

(A) Forest plot evaluated EAT for no-reflow. (B) Forest plot evaluated EAT divided by no-reflow and normal reflow. 
Risk Ratio

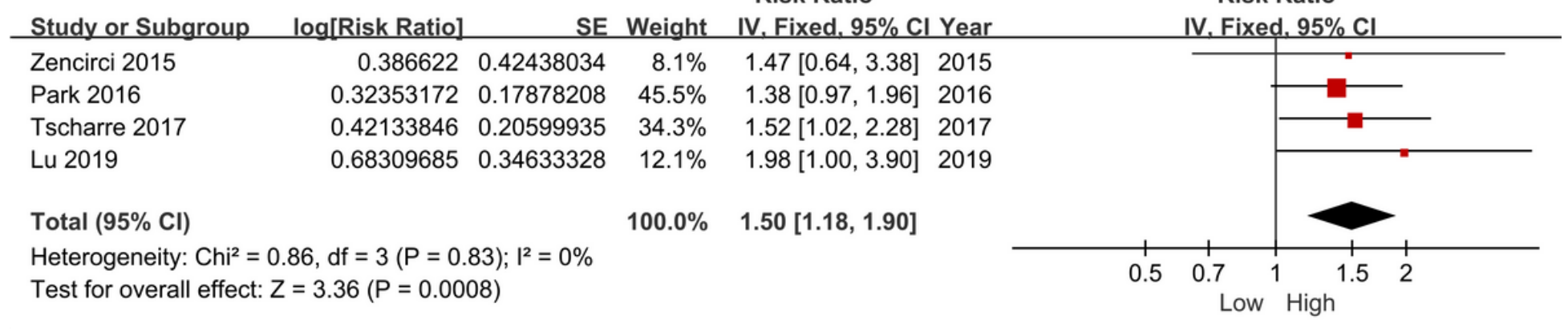

Figure 4

Forest plot evaluated EAT for MACE.

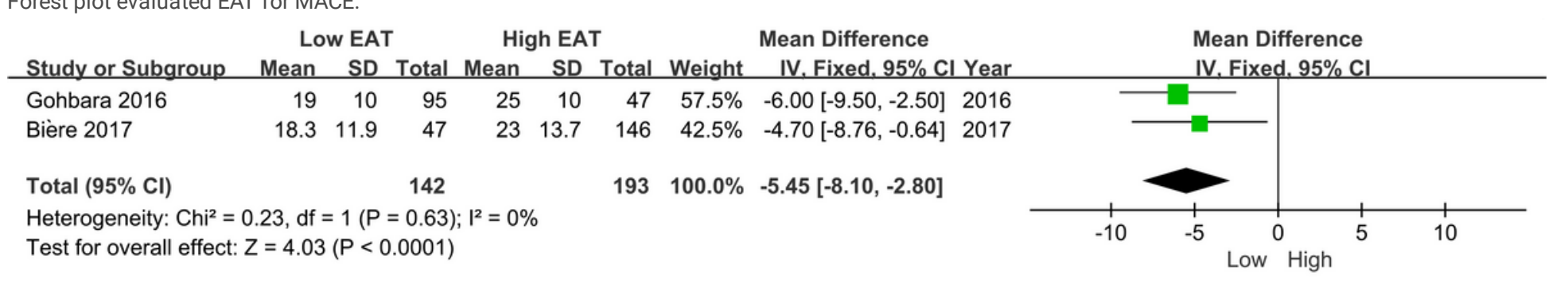

\section{Figure 5}

Forest plot evaluated EAT for infarct size.

\section{Supplementary Files}

This is a list of supplementary files associated with this preprint. Click to download.

- SupplementaryMaterial.doc 